\title{
Evidence for paternal imprinting in familial Beckwith-Wiedemann syndrome
}

\author{
Denis Viljoen, Rajkumar Ramesar
}

\begin{abstract}
A previously unreported family in which seven members in two generations have Beckwith-Wiedemann syndrome (BWS) is documented. Paternal imprinting of the gene responsible for BWS is involved as the mechanism responsible for the aberrant inheritance pattern in this kindred. A review of published reports showed 27 previously published pedigrees with two or more affected subjects with BWS. Paternal imprinting would explain the non-mendelian inheritance of BWS in all but four kindreds. The latter families are examined in more detail and in only one example is the evidence against imprinting totally unexplained.
\end{abstract}

Beckwith-Wiedemann syndrome (BWS) is characterised by variable clinical manifestations consisting of gigantism, macroglossia, exomphalos, visceromegaly, hemihypertrophy, earlobe grooves or pits, and occasional hypoglycaemia. Pathological features include hypertrophy or dysplasia of the islet cells of the pancreas, adrenal cortex, kidney, and liver, and a tendency to develop embryonal tumours. ${ }^{1}$ Several hundred cases of BWS have been reported, most of which have occurred sporadically. At least 27 kindreds with BWS have been published where two or more subjects are affected. ${ }^{2-23}$

In familial BWS the mode of inheritance is uncertain and various proposals include autosomal recessive, ${ }^{112024}$ autosomal dominant, ${ }^{2125}$ multifactorial, ${ }^{22627}$ and autosomal dominant sex dependent inheritance. ${ }^{14}$ Chromosomal duplications of the $11 \mathrm{p} 15.4$ region have also been associated with the BWS phenotype, ${ }^{28}$ as have persons with $11 \mathrm{p} 11$ and $11 \mathrm{p} 13$ deletions. ${ }^{29} 30$

Genetic imprinting has recently been implicated in the irregular inheritance patterns

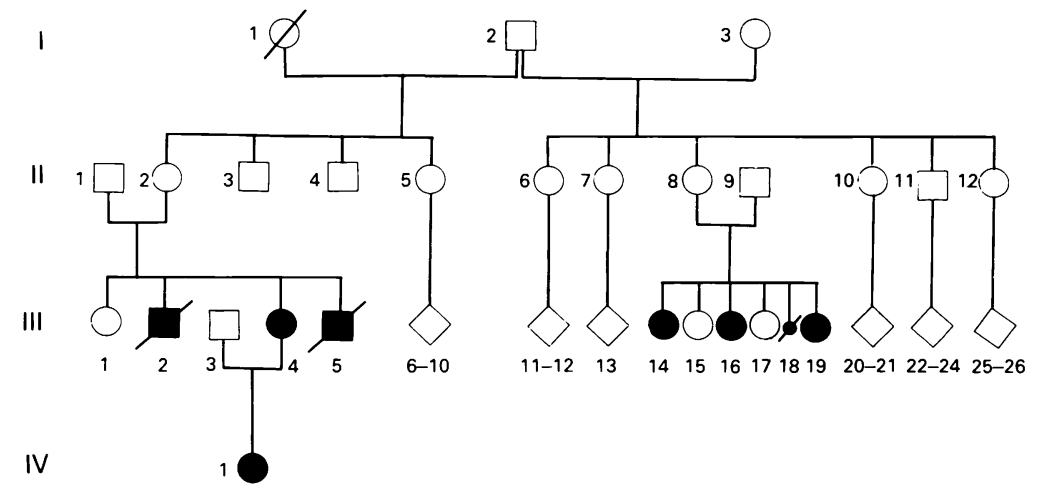

Figure 1 Pedigree of South African kindred with familial BWS. found in several disorders. ${ }^{31}{ }^{32}$ It can be defined as the functional difference between maternally and paternally derived chromosomes or their constituent parts. Imprinting may manifest through differential patterns of methylation and this mechanism is thought to account for the phenotypic differences in Prader-Willi and Angelman syndromes ${ }^{31}$ and for the phenomenon of 'normal transmitting males' in the fragile $\mathrm{X}$ syndrome. ${ }^{32}$ Genetic imprinting has been proposed to explain the non-mendelian pattern of inheritance in familial BWS..$^{31} 33$

We describe a further family in which seven subjects in two generations have BWS. In addition, 27 previously published pedigrees of familial BWS have been reviewed and concordance with the imprinting hypothesis has been found in all except four kindreds. The case for imprinting in such families is discussed in this paper.

\section{Family study}

The pedigree of the family under investigation is illustrated in fig 1 . Two phenotypically normal half sisters (patients II.2 and II.8) who have a common father (I.2) have each produced three offspring with the characteristic clinical manifestations of BWS. Two affected boys (III.2 and III.5) died in early infancy. They showed conclusive evidence of the disorder at necropsy. The remaining five affected relatives are all female, the oldest of whom (III.4) has had a daughter with BWS. The latter pregnancy was carefully monitored and prenatal diagnosis based on the ultrasonographic findings was performed and has been previously reported. ${ }^{25}$

The clinical manifestations of seven affected subjects are summarised in the table. The features most frequently found were macrosomia, macroglossia, and umbilical hernia. Creased ear lobes were evident in a few subjects, but ear lobe pits, omphalocele, hemihypertrophy, and hypoglycaemia were not features in our patients. Visceromegaly was noted in infancy but like hypertrophy of the tongue, these features became less pronounced in late childhood and reverted to normal in early adolescence. The clinical manifestations of patients III.4 (as an infant) and III.14, III.16, and III.19 are shown in figs 2 and 3, respectively.

\section{Discussion}

Seven members of the kindred described in this paper undoubtedly have BWS, with severe macroglossia representing the most 
Clinical manifestations of BWS patients.

\begin{tabular}{|c|c|c|c|c|c|c|c|c|}
\hline $\begin{array}{l}\text { Pedigree } \\
\text { No }\end{array}$ & Sex & $\begin{array}{c}\text { Birth } \\
\text { weight }(\mathrm{g})\end{array}$ & $\begin{array}{c}\text { Age at } \\
\text { examination }\end{array}$ & $\begin{array}{c}\text { Height } \\
(\mathrm{cm})\end{array}$ & $\begin{array}{l}\text { Umbilical } \\
\text { anomaly }\end{array}$ & Macroglossia & $\begin{array}{l}\text { Ear } \\
\text { lobe }\end{array}$ & $\begin{array}{l}\text { Other } \\
\text { features }\end{array}$ \\
\hline III. 2 & $\mathbf{M}$ & 3765 & Died at 5 days & 46 & + & ++ & - & Septicaemia, \\
\hline III.4 & $\mathbf{F}$ & 4886 & $21 \mathrm{y}$ & 179 & + & + & + & $\begin{array}{c}\text { kernicterus } \\
\text { Gigantism, typical } \\
\text { facies }\end{array}$ \\
\hline III.5 & $\mathbf{M}$ & 1540 & $\begin{array}{l}\text { Stillborn at } 28 / 52 \\
\text { gestation }\end{array}$ & - & + & + & - & - \\
\hline $\begin{array}{l}\text { III.14 } \\
\text { III.16 }\end{array}$ & $\begin{array}{l}\mathbf{F} \\
\mathbf{F}\end{array}$ & $\begin{array}{l}4540 \\
4800\end{array}$ & $\begin{array}{l}16 y \\
10 y\end{array}$ & $\begin{array}{l}169 \\
177\end{array}$ & $\begin{array}{l}- \\
-\end{array}$ & $\begin{array}{l}+ \\
+\end{array}$ & $\begin{array}{l}+ \\
+\end{array}$ & $\begin{array}{c}\text { Typical facies } \\
\text { Gigantism, typical } \\
\text { facies }\end{array}$ \\
\hline $\begin{array}{l}\text { III.19 } \\
\text { IV.1 }\end{array}$ & $\begin{array}{l}\mathrm{F} \\
\mathrm{F}\end{array}$ & $\begin{array}{l}5300 \\
5300\end{array}$ & $\begin{array}{c}5 \mathrm{w} \\
18 \mathrm{mth}\end{array}$ & $\begin{array}{r}64 \cdot 5 \\
87\end{array}$ & $\begin{array}{l}+ \\
+\end{array}$ & $\begin{array}{l}++ \\
++\end{array}$ & $\begin{array}{l}+ \\
+\end{array}$ & $\begin{array}{c}\text { Typicies } \\
\text { gigantism }\end{array}$ \\
\hline
\end{tabular}

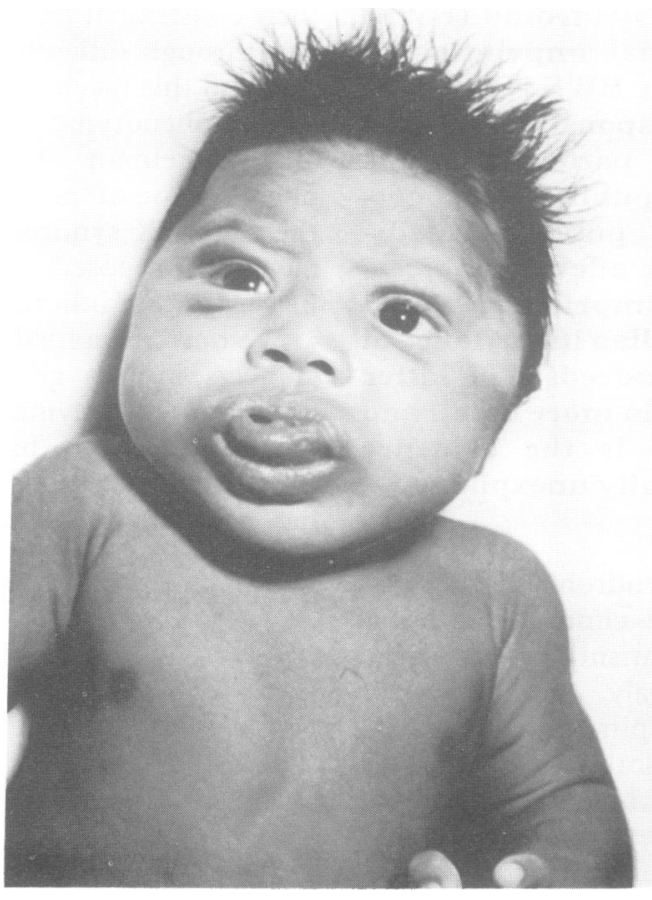

Figure 2 Patient III.4 as a neonate with signs of $B W S$. consistent clinical manifestation. The additional features of macrosomia, high birth weight, umbilical anomalies, creased ear lobes, and gigantism clinch the diagnosis. No instances of omphalocele, hemihypertrophy, or hypoglycaemia were recorded. The intrauterine ultrasonographic appearances of patient IV.1, which have been previously reported, ${ }^{25}$ included visceromegaly affecting the liver and kidneys, macrosomia, and macroglossia.

Difficulty was experienced in providing genetic counselling to this kindred, as the disorder appeared to be segregating as an irregular dominant trait. A computerised search of medical publications was made in order to gain insight into estimations of genetic risk for future pregnancies. Twenty-seven previously published pedigrees of familial BWS were elicited in which two or nıore subjects were affected. These are depicted in fig 4 and the separate kindreds labelled from $\mathrm{A}$ to $\mathrm{W}$. Isolated twin pregnancies were not included for analysis.

Several different descriptions of inheritance patterns in BWS have been reported previously. The original suggestion of autosomal recessive inheritance of $W_{\text {iedemann }}{ }^{20}$ and Beckwith $^{24}$ was supported by subsequent reports. ${ }^{11}$ Several authors ${ }^{2381214}$ ascribed an autosomal dominant mechanism to BWS while multifactorial inheritance may have played a role in families described by Wiedemann, ${ }^{27}$ Gardner, ${ }^{22}$ and Berry et al. ${ }^{26}$ Niikawa et al,${ }^{2}$ in a review of previously published pedigrees, strongly favoured autosomal dominant inheritance with variable expressivity to account for the inheritance anomalies.

Lubinsky et $a l^{14}$ proposed that autosomal dominant sex linked transmission could account for the inheritance pattern. These investigators postulated a 'two mutation' hypothesis in which the first mutation is transmitted in a dominant fashion and could involve a person of either sex, but who was phenotypically normal. The second mutation only occurred in the offspring of normal female carriers and the possibility of 'ovum mediated' expression of the disorder was hypothesised. Until recently, the 'two mutation' theory was generally accepted as the most probable explanation of the aberrant inheritance pattern in BWS.

Another rare association with BWS is duplication of the chromosome $11 \mathrm{p} 15.5$ region. The defect has been shown cytogenetically ${ }^{28-30} 3435$ and by molecular means. ${ }^{33} 36$ Deletions of the $11 \mathrm{p} 11^{29}$ and $11 \mathrm{p} 13$ regions $^{30}$ have
Figure 3 Three sisters (patients III.14, III.16, and III.19) with the typical facies of $B W S$. 

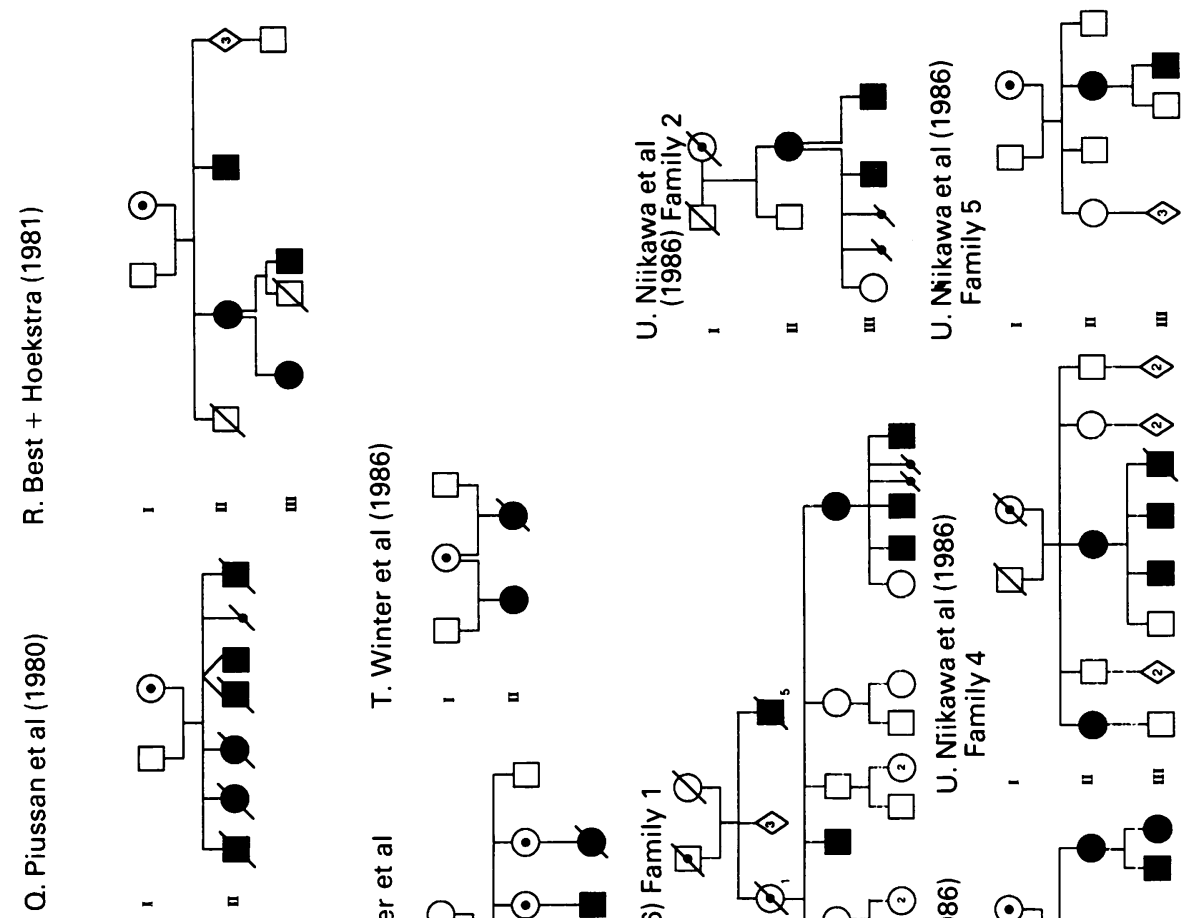

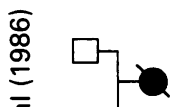
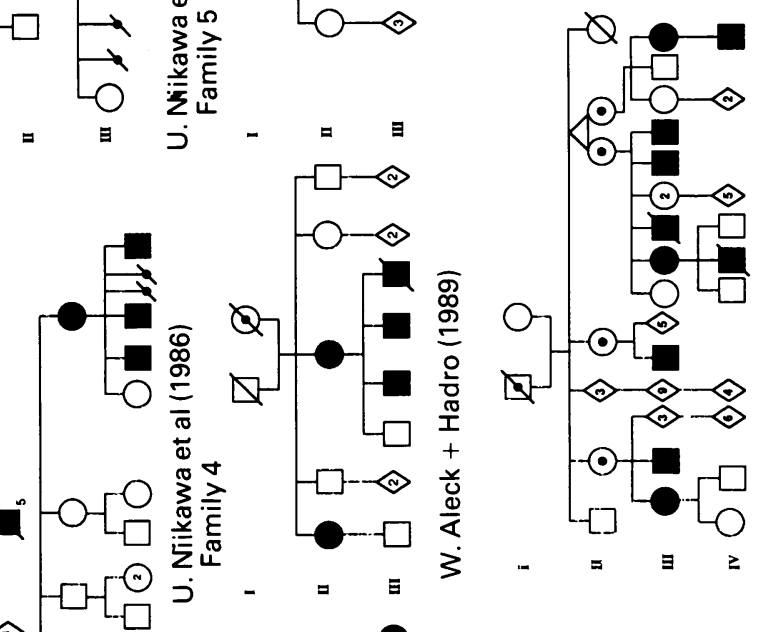

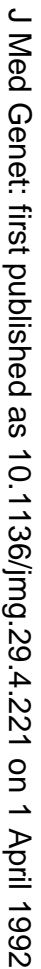
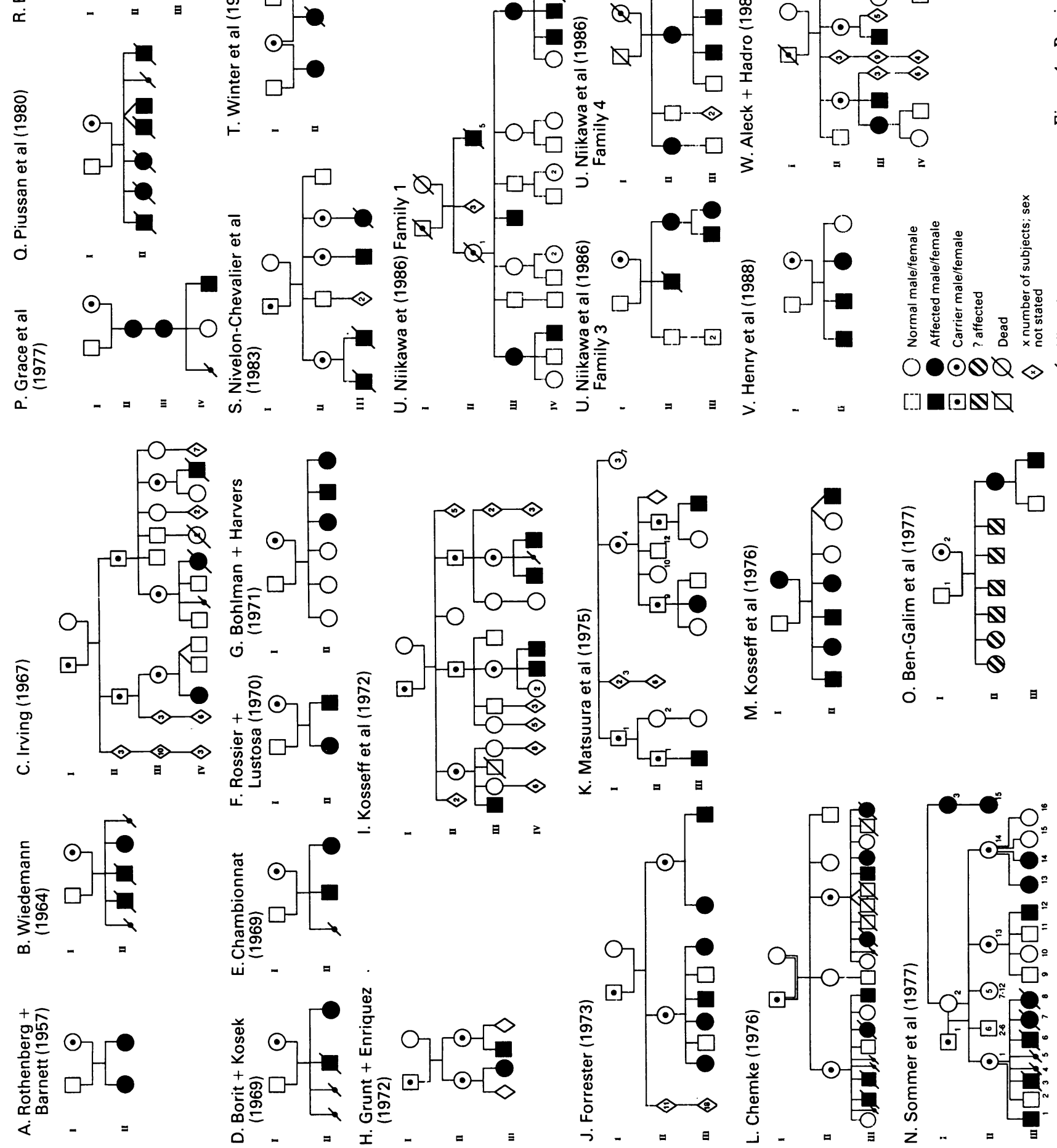
also been found in subjects with BWS. In most instances, mental retardation or congenital cardiac defects or both occurred, in the main sporadically. These features were not present in affected subjects in our family who were cytogenetically normal.

Increasingly, genetic imprinting has been postulated as the explanation for irregular or non-mendelian inheritance patterns in several unrelated disorders. ${ }^{3132}$ Koufos et $a^{l^{33}}$ and Hall $^{31}$ suggested that BWS and several other conditions such as glomus cell tumours, familial Wilms' tumour, and familial retinoblastoma may represent disorders where gene imprinting has occurred. Using this postulate, paternal imprinting of the BWS gene is the most likely explanation of the inheritance pattern seen in our family. If this scenario applied, the progenitor (patient I.2), who is phenotypically normal, would be a carrier for the imprinted gene and have a $50 \%$ chance of passing it on to his progeny, all of whom would lack stigmata of BWS. According to the hypothesis, a change of the imprint status of the BWS gene would occur in the germ line of female carriers (patients II.2 and II.8), and their own children, both male and female, would have a $50 \%$ risk of phenotypically manifesting the disorder (that is, $100 \%$ of gene carriers would be affected). Generation to generation transmission through affected females could occur, as between patients III.4 and IV.1, as the extant imprint status would be maintained. However, the imprint status of the BWS gene would be reversed in the germ line of affected or carrier males so that their progeny have a $50 \%$ risk of being carriers, but phenotypically normal.

A search of published reports has produced 27 kindreds of BWS patients (fig 4). The pedigrees have been reconstructed for the purposes of this paper indicating presumed male and female carriers in order to indicate the possibility of paternal imprinting. In all except four pedigrees (labelled $\mathrm{K}, \mathrm{N}, \mathrm{O}$, and $\mathrm{U}$ family 1 ), the pattern of inheritance is consistent with paternal genetic imprinting. One family which does not conform in this way was reported by Sommer et $a l^{19}$ (pedigree $\mathrm{N}$ ). If the male in generation $I$ is imprinted, then patients $I .3$ and II.15 are inconsistent with the proposed hypothesis. A possible explanation is that both latter subjects, who were not clinically appraised by the authors, did not have BWS Indeed, minor abdominal wall defects only were described (possible umbilical hernias). The remaining members of this kindred would fit the hypothesis of autosomal dominant inheritance and paternal imprinting.

Another previously published pedigree which was completely at variance with paternal imprinting as the mechanism of inheritance of familial BWS is that of Matsuura et $a l^{15}$ (pedigree $\mathrm{K}$ ). There is no plausible explanation for the inheritance pattern in this kindred in which three ostensible carrier males (II.1, II.9, and II.12) have produced affected offspring.

In the family reported by Ben-Galim $e t \mathrm{al}^{3}$ (pedigree $\mathrm{O}$ ), ear creases were said to be present in patient $I .1$ (the father). However, he had no other stigmata of BWS and it is more probable that patient I.2 was the carrier of the deimprinted BWS gene which then became manifest in her progeny.

Another kindred in which an ostensibly affected male (II.5) is at variance with paternal imprinting was published by Niikawa et $a l^{2}$ (pedigree $U$, family 1 ). This man had previously died and was not investigated by the authors. He had minimal signs of BWS according to the historical data collected. If this subject is excluded as being affected, the inheritance pattern is consistent with the imprinting hypothesis.

In conclusion, the retrospective published data and the kindred described in this paper provide strong supportive evidence for paternal imprinting in all but one instance of familial BWS. Acceptance of this hypothesis allows clear genetic counselling for subjects in BWS kindreds. In our family, five females in generation III are affected and they are all at a 50\% risk of producing affected progeny. Both female carriers (patients II.2 and II.8) are similarly at risk should they have further offspring. No living males remain in generation III, but hypothetically such subjects would have a $50 \%$ chance of producing offspring who are carriers of BWS. Prenatal diagnosis is then feasible by ultrasonography ${ }^{232537}$ for any subject at risk, or through RFLP analysis. ${ }^{33}$ The exact mechanism of imprinting in BWS is unknown at present but the possibility of differential methylation of the 11 p 15.5 region is currently being investigated using VNTR polymorphisms for that chromosomal region.

We are grateful to Nursing Sisters Young, Beatty, Balchin, Van Vuuren, and Naidoo for their help with the families, and to Bonita Plato for typing the manuscript. This research was supported by grants from the South African Medical Council, the Mauerberger Foundation, the Harry Crossley Foundation, and the University of Cape Town Staff Research Fund.

1 Jones KL. Beckwith-Wiedemann syndrome. In: Smith's recognizable patterns of human malformation. 4th ed. Philrecognizable patterns of human malfo

2 Niikawa N, Ishikiriyama S, Takahashi S, et al. The Wiedemann-Beckwith syndrome: pedigree studies on five families with evidence for autosomal dominant inheritance with variable expressivity. $\mathrm{Am}$ f $\mathrm{Med}$ Genet 1986;24:41-55.

3 Ben-Galim E, Gross-Kieselstein E, Abrahamov A. Beckwith-Wiedemann syndrome in a mother and her son. Am $\mathcal{F}$ Dis Child 1977;131:801-3.

4 Bohlmann H-G, Harvers W. Exomphalos-MakroglossieGigantismus-Syndrom (Wiedemann-Beckwith Syndrom) bei drei Geschwistern. Arch Kinderheilkd 1971;183:175-82.

5 Borit A, Kosek J. Cytomegaly of the adrenal cortex. Arch Pathol Lab Med 1969;88:58-64.

6 Chambionnat D. A propos de deux nouveau cas d'un syndrome associant une omphalocèle, une macroglossie, synerome une macrosomie-

7 Cheme J. Familial macroglossia-omphalocele syndrome $\mathcal{f}$ Genet Hum 1976;24:271-9.

8 Forrester RM. Wiedemann-Beckwith syndrome. Lancet 1973;ii:47.

9 Grace JB, Heroman WM, Kornblut AD. Macroglossia in the Beckwith-Wiedemann syndrome. Trans Am Acad Ophthalmol Otol 1977;84:116-9.

10 Grunt JA, Enriquez AR. Further studies of the hypoglycemia in children with the exomphalos-macroglossiamia in children with the exomphalos-macroglossia-

11 Irving IM. Exomphalos with macroglossia: a study of eleven cases. F Pediatr Surg 1967;2:499-507. 
12 Kosseff AL, Herrmann J, Opitz JM. The WiedemannBeckwith syndrome: genetic considerations and a dia Beckwith syndrome: genetic cons
gnostic sign. Lancet $1972 ; \mathbf{i}: 844$.

13 Kosseff AL, Hermann J, Gilbert EF, Visekul C, Lubinsky M, Opitz JM. Studies of malformation syndromes of man. XXIX. The Wiedemann-Beckwith syndrome. Clinical, genetic and pathogenetic studies of 12 cases. Eur f Pediatr 1976;123:139-66.

14 Lubinsky M, Herrmann J, Kosseff A, Opitz JM Autosomal-dominant sex-dependent transmission of the Wiedemann-Beckwith syndrome. Lancet 1974;i:932.

15 Matsuura N, Endo M, Okayasu T, Okuno A. WiedemannBeckwith syndrome. Lancet 1975;ii:508.

16 Piussan Ch, Risbourg B, Lenaerts C, Delvallez N, Gontier MF, Viste M. Syndrome de Wiedemann et Beckwith: une nouvelle observation familiale. If Genet Hum 1980 28:281-91.

17 Rossier A, Lustosa ML. Syndrome d'hypertrophie staturale avec macroglossie et omphalocèle (WiedemannBeckwith). Ann Pediatr (Paris) 1970;17:452-6.

18 Rothenberg RE, Barnett T. Omphalocele in siblings. Report of two cases with surgical recovery. Arch Surg port of two cases
$1957 ; 75: 131-4$.

19 Sommer A, Cutler EA, Cohen BL, Harper D, Backes C. Familial occurrence of the Wiedemann-Beckwith syndrome and persistent fontanel. Am $\mathcal{f}$ Med Genet 1977;1:59-63.

20 Wiedemann H-R. Complexe malformatif familial avec hernie ombilicale et macroglossie-un "syndrome nouveau"? If Genet Hum 1964;13:223-32.

21 Aleck KA, Hadro TA. Dominant inheritance of Wiedemann-Beckwith syndrome: further evidence for transmission of "unstable premutation" through carrie women. Am $\mathcal{F}$ Med Genet 1989;33:155-60.

22 Gardner LI. Pseudo-Beckwith-Wiedemann syndrome: in teraction with maternal diabetes. Lancet 1973;ii:911-2.

23 Nivelon-Chevallier A, Mavel A, Michiels R, Bethenod M Syndrome de Wiedemann Beckwith-familial: diagnostic antenatal echographique et confirmation histologique. $\mathcal{F}$
Genet Hum 1983;31:397-402.

24 Beckwith JB. Macroglossia, omphalocele, adrenal cytomegaly, gigantism, and hyperplastic visceromegaly. Birth Defects 1969;2:188-96.
25 Viljoen DL, Jaquire Z, Woods DL. Prenatal diagnosis in autosomal dominant Beckwith-Wiedemann syndrome. autosomal dominant Beckwith-

26 Berry AC, Belton EM, Chantler C. Monozygotic twins discordant for Wiedemann-Beckwith syndrome and the implications for genetic counselling. $f$ Med Genet 1980;17:136-8.

27 Wiedemann HR. EMG syndrome. Lancet 1973;ii:626-7.

28 Turleau $C$,e Grouchy J, Chavin-Colin F, Martelli $H$, Voyer M, Charles R. Trisomy $11 \mathrm{p} 15$ and BeckwithWiedemann syndrome. A report of 2 cases. Hum Genet 1984;67:219-21.

29 Haas OA, Zoubek A, Grumayer ER, Gadner H. Constitutional interstitial deletion of $11 \mathrm{p} 11$ and pericentric inversion of chromosome 9 , in a patient with WiedemannBeckwith syndrome and hepatoblastoma. Cancer Genet Cytogenet 1986;23:95-104.

30 Schmutz SM. Deletion of chromosome 11 (p11p13) in a patient with Beckwith-Wiedemann syndrome. Clin Genet 1986;30:154-6.

31 Hall JG. How imprinting is relevant to human disease. Development 1990;(suppl):141-8.

32 Clarke A. Genetic imprinting in clinical genetics. Development 1990;(suppl):131-9.

33 Koufos A, Grundy P, Morgan K, et al. Familial Wiedemann-Beckwith syndrome and a second Wilms tumor locus both map to $11 \mathrm{p} 15.5$. Am $\mathcal{F} \mathrm{Hum}$ Genet 1989;44:711-9.

34 Waziri M, Patil SR, Hanson JW, Bartley JA. Abnormality of chromosome 11 in patients with features of BeckwithWiedemann syndrome. 7 Pediatr 1983;102:873-6.

35 Journel $\mathrm{H}$, Lucas J, Allaire C, et al. Trisomy $11 \mathrm{p} 15$ and Beckwith-Wiedemann syndrome: report of two new cases. Am $\mathcal{f}$ Hum Genet 1985;28:97-101.

36 Henry I, Jeanpierre M, Barichard F, et al. Duplication of HRAS1, INS, and IGF2 is not a common event in Beckwith-Wiedemann syndrome. Ann Genet (Paris) 1988;31:216-20.

37 Winter SC, Curry CJR, Smith JC, Kassel S, Miller L, Andrea J. Prenatal diagnosis of the Beckwith-Wiedemann syndrome. Am f Med Genet 1986;24:137-41. 